\title{
Pseudomonas plecoglossicida sp. nov., the causative agent of bacterial haemorrhagic ascites of ayu, Plecoglossus altivelis
}

\author{
E. Nishimori, ${ }^{1}$ K. Kita-Tsukamoto ${ }^{2}$ and H. Wakabayashi ${ }^{1}$ \\ Author for correspondence: H. Wakabayashi. Tel: +8135841 5282. Fax: +8135841 8165. \\ e-mail: ahisa@hongo.ecc.u-tokyo.ac.jp
}

\footnotetext{
1 Department of Aquatic Bioscience, Graduate School of Agricultural and Life Sciences, University of Tokyo, 1-1-1 Yayoi, Bunkyo-ku, Tokyo 113-8657, Japan

2 Ocean Research Institute, University of Tokyo, 1-15-1 Minamidai, Nakano-ku, Tokyo 164-8639, Japan
}

\begin{abstract}
A new Pseudomonas species, for which the name Pseudomonas plecoglossicida is proposed, was isolated from cultured ayu (Plecoglossus altivelis) with bacterial haemorrhagic ascites. The causative agent was similar to Pseudomonas putida biovar $A$ in its phenotypic characteristics and on the basis of 165 rRNA gene sequence analysis, but it reduced nitrate to nitrite. Furthermore, it was distinguished phenotypically from Pseudomonas putida biovar A by utilization of D-malate, L-(+)-tartrate, $m$-tartrate and nicotinate. The levels of DNA-DNA hybridization between the isolate strain FPC $951^{\top}$ and other reference strains of Pseudomonas species, including Pseudomonas putida, were less than $50 \%$. The G+C content of the DNA of FPC $951^{\top}$ was $62.8 \mathrm{~mol} \%$. Strain FPC $951^{\mathrm{T}}$ ( = ATCC 700383') is designated the type strain of the new species.
\end{abstract}

Keywords: Pseudomonas plecoglossicida, taxonomy, fish pathogen, ayu, Plecoglossus altivelis

\section{INTRODUCTION}

Since the early 1990s, a new bacterial disease has caused mass mortalities among pond-cultured ayu (Plecoglossus altivelis) in Japan. Wakabayashi et al. (1996) named it bacterial haemorrhagic ascites (BHA) of ayu, because bloody ascites commonly occurred. Recently, pejerrey (Odonthestes bonariensis) farmed in Japan has also been affected with BHA. A pseudomonad has always been isolated from the internal organs of the diseased fish. The isolates, when inoculated artificially, had high mortality to ayu and could be reisolated from the inoculated fish.

The organisms are Gram-negative, aerobic, rodshaped bacteria, motile by several polar flagella. They are cytochrome-oxidase-positive and oxidize but do not ferment glucose. Most of the isolates have the API 20 NE profile 1-140-457, which is not found in the API profile database (API 20NE analytical profile index, 5th edition; BioMérieux) (Wakabayashi et al., 1996).

Some Pseudomonas species have been reported to be causative agents of fish disease: Pseudomonas anguilliseptica was described as a pathogen in eel (Anguilla

The DDBJ accession number for the 165 rRNA gene sequence of Pseudomonas plecoglossicida FPC $951^{\top}$ is AB009457. japonica) (Wakabayashi \& Egusa, 1972) and ayu (Nakai et al., 1985), Pseudomonas fluorescens in carp (Shiose et al., 1974), sea bream (Evynnis japonica) (Kusuda et al., 1974) and tilapia (Sarotherodon niloticus) (Miyashita, 1984), Pseudomonas chlororaphis in amago trout (Onchorhynchus rhodurus) (Hatai et al., 1975) and Pseudomonas putida in yellowtail (Seriola quinqueradiata) (Kusuda \& Toyoshima, 1976).

The genus Pseudomonas is recognized as a large and widely diverse bacterial group (Palleroni et al., 1973). Up to the present, many arguments about the taxonomy of this genus have been put forward (Segers et al., 1994; Tamaoka et al., 1987; Willems et al., 1989, 1990; Yabuuchi et al., 1990, 1992, 1995). Its classification has been basically done with phenotypic characterization (Stanier et al., 1966) and nucleic acid homology (Palleroni et al., 1973). Palleroni et al. (1973) subdivided Pseudomonas species into five main groups on the basis of rRNA-DNA hybridization. According to this classification, all fish-pathogenic Pseudomonas belong to rRNA group I, which has been recently regarded as Pseudomonas sensu stricto (Kersters et al., 1996).

In this paper, we present evidence that the isolates from ayu with BHA constitute a new species on the basis of phenotypic characteristics and molecular 
genetic methods, 16S rRNA gene (rDNA) sequence analysis and DNA-DNA hybridization. We propose the name Pseudomonas plecoglossicida sp. nov. for the bacterium.

\section{METHODS}

Bacterial strains. The following six bacterial strains studied were isolated from ayu with BHA: strains FPC 951 ATCC $700383^{\mathrm{T}}$ ) and FPC 952 isolated in March 1994 in Tokushima Prefecture, strains FPC 941 (= ATCC 700384) and FPC 940 in January 1994 in Shiga Prefecture, strain FPC 975 in August 1995 in Nagano Prefecture, and strain FPC 976 in June 1991 in Wakayama Prefecture, Japan. The strains were isolated by streaking portions of kidney tissues on tryptic soy agar (TSA). The bacteria were stored in tryptic soy broth (TSB) containing $10 \%$ glycerol at $-80^{\circ} \mathrm{C}$. All of the results were based on cultures incubated at $25^{\circ} \mathrm{C}$ unless otherwise noted.

Phenotypic characterization. Cell morphology was recorded from light microscope observations of a Gram-stained smear preparation and also from electron microscope observations of a negatively stained preparation.

Biochemical characteristics, firstly, were determined with commercially produced kit systems (API $20 \mathrm{NE}$ and API ZYM; BioMérieux). To investigate further physiological and biochemical characteristics, we used methods described by Stanier et al. (1966) and Palleroni \& Doudoroff (1972) for the following tests: the oxidase reaction, the accumulation of poly- $\beta$-hydroxybutyrate, levan formation from sucrose, the egg-yolk reaction, the production of extracellular lipase, hydrolysis of gelatin and starch, and denitrification. The temperature range for growth was examined in TSA using a temperature gradient incubator (TN-3; Toyo kagaku sangyo) for $7 \mathrm{~d}$. Fluorescent pigment was observed on King medium A and King medium B (Eiken Chemical) (King et al., 1954). Arginine dihydrolase was determined in Møller's decarboxylase base (Difco Laboratories) (MacFaddin, 1980). Carbon source utilization tests were performed in the basal medium of Stanier et al. (1966) and Véron (1975) by using 96-well microplates described by Ishimaru et al. (1995). Growth was determined at $25^{\circ} \mathrm{C}$ for $7 \mathrm{~d}$ and growth greater than the control without carbon source was regarded as positive.

DNA extraction. Chromosomal DNA was extracted by a slightly modified procedure of Wilson (1987). Five hundred milligrammes wet weight bacterial cells was resuspended in $11.3 \mathrm{ml}$ TE buffer (10 mM Tris/HCl, 1 mM EDTA, $\mathrm{pH} 8 \cdot 0)$. Cells were lysed by $10 \%$ SDS and proteinase $\mathrm{K}\left(20 \mathrm{mg} \mathrm{ml}^{-1}\right.$; Sigma). After cetyltrimethylammonium bromide $/ \mathrm{NaCl}$ treatment, the DNA was further purified by chloroform/ isoamyl alcohol $(24: 1, \mathrm{v} / \mathrm{v})$, phenol/chloroform/isoamyl alcohol (25:24: 1, by vol.) and RNase A (10 $\mathrm{mg} \mathrm{ml}^{-1}$; Sigma). The DNA concentration and purity of each DNA sample were determined by measuring the $A_{260}$ and $A_{260} / A_{280}$ ratio, respectively.

16S rDNA sequence determination. The 16S rRNA genes were amplified using PCR (Saiki et al., 1988) with Taq polymerase (Toyobo) and the universal primer pair of $20 \mathrm{~F}$ (5'-AGA GTT TGA TCC TGG CTC AG-3') and 1500R (5'GGT TAC CTT GTT ACG ACT T-3') described by Weisburg et al. (1991). PCR amplifications were performed in $50 \mu \mathrm{l}$ reaction mixture containing buffer, $1.5 \mathrm{mM} \mathrm{MgCl}$, $0.5 \mathrm{nmol}$ each deoxynucleoside triphosphate, $10 \mathrm{pmol}$ each primer, $2.5 \mathrm{U} \mathrm{Taq}$ polymerase and the template DNA, by using the DNA thermal cycler (GeneAmp PCR system 2400; Perkin-Elmer) with the following temperature profile: an initial denaturation at $94{ }^{\circ} \mathrm{C}$ for 2 min; 30 cycles of denaturation $\left(2 \mathrm{~min}\right.$ at $\left.94^{\circ} \mathrm{C}\right)$, annealing $\left(1.5 \mathrm{~min}\right.$ at $\left.50^{\circ} \mathrm{C}\right)$ and extension $\left(2 \mathrm{~min}\right.$ at $\left.72{ }^{\circ} \mathrm{C}\right)$; and a final extension at $72^{\circ} \mathrm{C}$ for $2 \mathrm{~min}$. The PCR products purified with a Microcon-100 microconcentrator (Amicon) were sequenced directly using a Taq DyeDeoxy Terminator Cycle Sequencing kit (Applied Biosystems). Sequence reaction mixtures were electrophoresed and analysed with an Applied Biosystems model 377A DNA sequencer.

Phylogenetic analysis. The 16S rDNA sequences determined were then aligned with reference sequences obtained from databases using the CLUSTAL W program (Thompson et al., 1994). Pairwise evolutionary distances of them were calculated using Kimura's two-parameter model (Kimura, 1980). A phylogenetic tree from distance matrices was constructed by the neighbour-joining method (Saitou \& Nei, 1987), and the topology of it was evaluated using a CLUSTAL $\mathrm{w}$ bootstrap analysis with 1000 replicates.

DNA-DNA hybridization. DNA homology determination followed the quantitative dot blot hybridization method described by Ezaki et al. (1988) using photobiotin (Vector laboratories) for labelling DNA probes and streptavidinalkaline phosphatase conjugate (Gibco-BRL) and the 5bromo-4-chloro-3-indolyl phosphate/nitro blue tetrazolium phosphatase substrate system (Kirkegaard \& Perry Lab.) for detecting hybridized spots, according to the protocols supplied by the manufacturers. Quantification of hybridized spots was determined essentially as described by Hiraishi et al. (1991) using a densitograph imaging analyser (type AE-6920-MFS; Atto) for measuring the spots. Each hybridization experiment was done twice.

DNA base composition. The $\mathrm{G}+\mathrm{C}$ content of DNA was determined by the thermal denaturation method (Marmur \& Doty, 1962). DNA from Escherichia coli strain K-12 was used as a standard.

Nucleotide sequence accession numbers. The $16 \mathrm{~S}$ rRNA gene sequence of Pseudomonas plecoglossicida FPC $951^{\mathrm{T}}$ has been deposited in DDBJ under accession number AB009457. The strain designations and accession numbers of $16 \mathrm{~S}$ rRNA gene sequences of other species that were compared with the FPC $951^{\mathrm{T}}$ sequence in this study are as follows: Pseudomonas aeruginosa LMG 1242 ${ }^{\mathrm{T}}$ (Z76651), Pseudomonas asplenii LMG $2137^{\mathrm{T}}$ (Z76655), Pseudomonas aureofaciens DSM 6698 ${ }^{\mathrm{T}}$ (Z76656), Pseudomonas chlororaphis LMG 5004 (Z76657), Pseudomonas flavescens B62 ${ }^{\mathrm{T}}$ (U01916), Pseudomonas fluorescens IAM 12022 ${ }^{\mathrm{T}}$ (D84013), Pseudomonas mendocina LMG 1223 ${ }^{\mathrm{T}}$ (Z76664), Pseudomonas putida biovar A DMS 291 ${ }^{\mathrm{T}}(\mathrm{Z} 76667)$, Pseudomonas putida biovar B MnB1 (U70977), Pseudomonas stutzeri ATCC 17591 (U26261), Escherichia coli MRE 600 (J01859), Burkholderia cepacia ATCC 25416 (M22518), Comamonas testosteroni ATCC 11996 (M11224), Brevundimonas diminuta ATCC 11568 (M59064) and Stenotrophomonas maltophilia ATCC 13637 (M59158).

\section{RESULTS}

\section{Phenotypic characteristics}

Six isolates had the same phenotypic properties. Cells were Gram-negative rods measuring 0.5-1× $2 \cdot 5-4 \cdot 5 \mu \mathrm{m}$. They were motile by polar multitrichous 


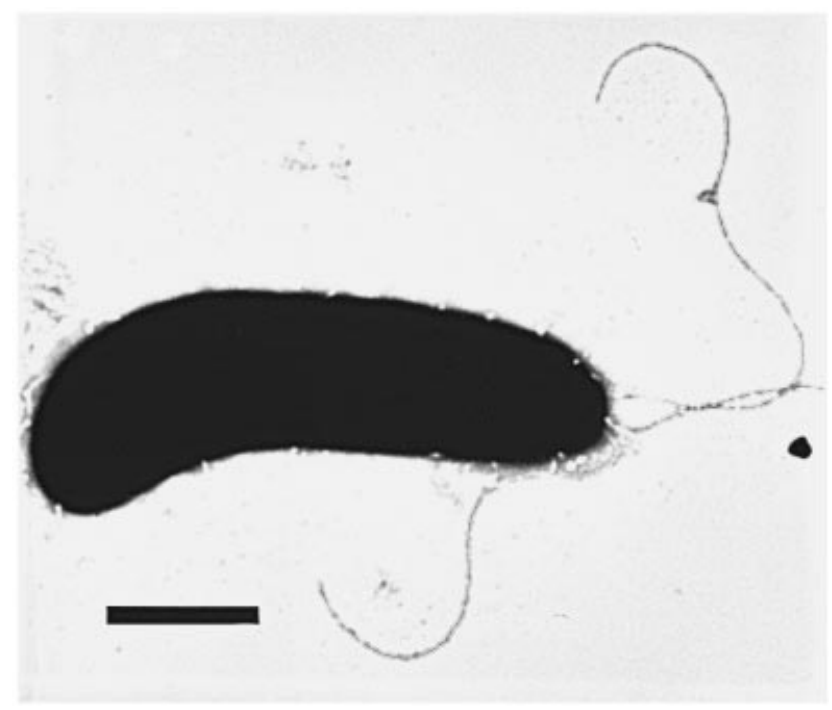

Fig. 1. Electron micrograph of negatively stained cells of Pseudomonas plecoglossicida FPC 951 ${ }^{\top}$. Bar, $1 \mu \mathrm{m}$.

flagella (Fig. 1), and sometimes single or no flagellated cells were observed. On tryptic soy medium, growth occurred at $10-30{ }^{\circ} \mathrm{C}$ in the presence of $0-5 \% \mathrm{NaCl}$, and at $\mathrm{pH}$ 5-9. Metabolism was respiratory, not fermentative. The cytochrome oxidase test was positive. Nitrate reduction was positive, but denitrification was negative. Fluorescent pigment was produced weakly on King medium B. A summary of phenotypic properties is shown in Table 1 .

\section{S rRNA gene sequence analysis}

Two strains of the isolate, FPC $951^{\mathrm{T}}$ and FPC 941, were selected to use for $16 \mathrm{~S}$ rRNA gene sequence analysis. Pseudomonas plecoglossicida FPC $951^{\mathrm{T}}$ had the same 16S rDNA sequence as strain FPC 941. A phylogenetic tree derived from 16S rRNA gene sequences was used to illustrate the position of Pseudomonas plecoglossicida FPC $951^{\mathrm{T}}$ and other Pseudomonas species belonging to rRNA groups I-V in Fig. 2. It indicated that Pseudomonas plecoglossicida FPC $951^{\mathrm{T}}$ was placed in rRNA group I. The similarities $(\%)$ in $16 \mathrm{~S}$ rDNA sequences of Pseudomonas plecoglossicida FPC $951^{\mathrm{T}}$ with other closely related Pseudomonas species belonging to rRNA group I were: Pseudomonas aeruginosa LMG $1242^{\mathrm{T}}$, 95.9\% ; Pseudomonas asplenii LMG $2137^{\mathrm{T}}$, 98.4\%; Pseudomonas aureofaciens DSM $6698^{\mathrm{T}}, 97 \cdot 1 \%$; Pseudomonas chlororaphis LMG $5004^{\mathrm{T}}, 97 \cdot 1 \%$; Pseudomonas flavescens $\mathrm{B} 62^{\mathrm{T}}, 98.2 \%$; Pseudomonas fluorescens IAM $12022^{\mathrm{T}}, 96.2 \%$; Pseudomonas mendocina LMG $1223^{\mathrm{T}}$, $97.4 \%$; Pseudomonas putida biovar A DMS $291^{\mathrm{T}}$,

Table 1. Characteristics for differentiating Pseudomonas plecoglossicida from other Pseudomonas species

Data for all Pseudomonas species other than Pseudomonas plecoglossicida are from Palleroni (1984). +, 90\% or more strains are positive;,$- 90 \%$ or more strains are negative; $d, 11-89 \%$ of strains are positive.

\begin{tabular}{|c|c|c|c|c|c|c|c|c|c|}
\hline Characteristic & P. plecoglossicida & $P$. aeruginosa & P. fluorescens & P. chlororaphis & P. aureofaciens & P. putida bv. A & P. putida bv. B & P. stutzeri & P. mendocina \\
\hline No. of flagella & $>1$ & 1 & $>1$ & $>1$ & $>1$ & $>1$ & $>1$ & 1 & 1 \\
\hline Fluorescent pigments & + & $\mathrm{d}$ & $\mathrm{d}$ & + & + & + & $\mathrm{d}$ & - & - \\
\hline Growth at $4{ }^{\circ} \mathrm{C}$ & - & - & $\mathrm{d}$ & + & + & $\mathrm{d}$ & + & - & - \\
\hline Growth at $41{ }^{\circ} \mathrm{C}$ & - & + & - & - & - & - & - & + & + \\
\hline Arginine dihydrolase & + & + & + & + & + & + & + & - & + \\
\hline Denitrification & - & + & $\mathrm{d}$ & + & - & - & - & + & + \\
\hline Levan formation from sucrose & - & - & $\mathrm{d}$ & + & + & - & - & - & - \\
\hline Gelatin liquefaction & - & + & + & + & + & - & - & - & - \\
\hline Lecithinase (egg yolk) & - & - & $\mathrm{d}$ & + & $\mathrm{d}$ & - & - & - & - \\
\hline Lipase (Tween 80 hydrolysis) & - & \pm & $\mathrm{d}$ & + & $\mathrm{d}$ & $\mathrm{d}$ & $\mathrm{d}$ & + & + \\
\hline \multicolumn{10}{|l|}{ Utilization of: } \\
\hline Mannitol & - & + & $\mathrm{d}$ & + & + & $\mathrm{d}$ & $\mathrm{d}$ & $\mathrm{d}$ & - \\
\hline D-Xylose & - & - & $\mathrm{d}$ & - & - & $\mathrm{d}$ & $\mathrm{d}$ & - & - \\
\hline L-Arabinose & - & - & $\mathrm{d}$ & - & + & $\mathrm{d}$ & + & - & - \\
\hline D-Mannose & - & - & $\mathrm{d}$ & + & + & $\mathrm{d}$ & $\mathrm{d}$ & - & - \\
\hline Sucrose & - & - & $\mathrm{d}$ & + & $\mathrm{d}$ & - & $\mathrm{d}$ & - & - \\
\hline Trehalose & - & - & $\mathrm{d}$ & + & $\mathrm{d}$ & - & - & - & - \\
\hline 2-Ketogluconate & + & + & $\mathrm{d}$ & + & $\mathrm{d}$ & $\mathrm{d}$ & + & - & - \\
\hline D-Malate & + & $\mathrm{d}$ & $\mathrm{d}$ & $\mathrm{d}$ & - & $\mathrm{d}$ & $\mathrm{d}$ & $\mathrm{d}$ & $\mathrm{d}$ \\
\hline $\mathrm{D}(-)$-Tartrate & - & - & $\mathrm{d}$ & - & - & $\mathrm{d}$ & d & - & - \\
\hline $\mathrm{L}(+)$-Tartrate & - & - & $\mathrm{d}$ & $\mathrm{d}$ & - & $\mathrm{d}$ & $\mathrm{d}$ & - & $\mathrm{d}$ \\
\hline$m$-Tartrate & - & - & $\mathrm{d}$ & - & - & $\mathrm{d}$ & - & - & - \\
\hline$m$-Inositol & - & - & d & + & + & - & - & - & - \\
\hline Propylene glycol & + & + & d & - & - & $\mathrm{d}$ & + & + & + \\
\hline Phenyl acetate & + & + & $\mathrm{d}$ & $\mathrm{d}$ & + & $\mathrm{d}$ & + & - & - \\
\hline Testosterone & - & - & - & - & - & - & + & - & - \\
\hline L-Lysine & + & + & d & $\mathrm{d}$ & $\mathrm{d}$ & + & $\mathrm{d}$ & - & - \\
\hline L-Citrulline & + & $\mathrm{d}$ & d & $\mathrm{d}$ & $\mathrm{d}$ & $\mathrm{d}$ & $\mathrm{d}$ & - & - \\
\hline L-Tryptophan & - & $\mathrm{d}$ & d & + & + & - & + & - & - \\
\hline L-Kynurenine & - & + & d & + & + & - & + & - & - \\
\hline Anthranilate & - & + & d & + & + & - & + & - & - \\
\hline Nicotinate & - & - & d & - & - & $\mathrm{d}$ & + & - & - \\
\hline DNA $\mathrm{mol} \% \mathrm{G}+\mathrm{C}$ & $62 \cdot 8$ & $67 \cdot 2$ & $59 \cdot 4-61 \cdot 3$ & $63 \cdot 5$ & $63 \cdot 6$ & $62 \cdot 5$ & $60 \cdot 7$ & $60 \cdot 6-66 \cdot 3$ & $62 \cdot 8-64 \cdot 3$ \\
\hline
\end{tabular}




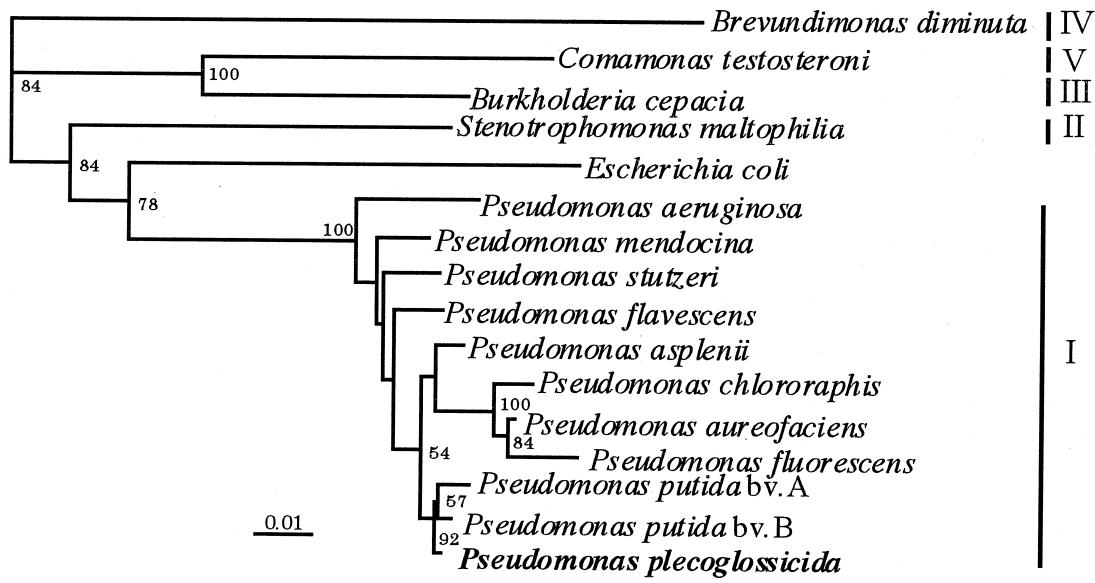

Fig. 2. Phylogenetic tree based on $16 \mathrm{~S}$ rRNA gene sequences of Pseudomonas plecoglossicida, E. coli, and other species belonging to Pseudomonas rRNA groups I-V. Roman numerals on the right indicate the number of the Pseudomonas rRNA group described by Palleroni et al. (1973). The tree was generated by the neighbourjoining method. Numbers at nodes show the levels of bootstrap support based on data for 1000 replicates; only values that are more than $50 \%$ are shown. Bar, 0.01 substitution per nucleotide position.

Table 2. Percentage DNA-DNA hybridization between Pseudomonas plecoglossicida sp. nov. strains FPC $951^{\top}$ and FPC 941 and closely related Pseudomonas species

\begin{tabular}{|c|c|c|c|}
\hline \multirow[t]{2}{*}{ Species } & \multirow[t]{2}{*}{ Strain* } & \multicolumn{2}{|c|}{ DNA-DNA hybridization ( $\%$ ) } \\
\hline & & FPC $951^{\mathrm{T}}$ & FPC 941 \\
\hline \multirow[t]{4}{*}{ Pseudomonas plecoglossicida } & FPC $951^{\mathrm{T}}$ & 100 & \\
\hline & FPC 941 & 96 & 100 \\
\hline & FPC 975 & 94 & 108 \\
\hline & FPC 976 & 96 & 104 \\
\hline \multirow[t]{3}{*}{ Pseudomonas putida bv. A } & ATCC $12633^{\mathrm{T}}$ & 47 & 47 \\
\hline & IAM 1218 & 24 & 26 \\
\hline & IAM 1235 & 32 & 33 \\
\hline \multirow[t]{2}{*}{ Pseudomonas putida bv. B } & ATCC 17472 & 33 & 35 \\
\hline & ATCC 23483 & 40 & 40 \\
\hline Pseudomonas asplenii & ATCC $23835^{\mathrm{T}}$ & 21 & 20 \\
\hline Pseudomonas aureofaciens & IAM 12353 & 22 & 24 \\
\hline Pseudomonas chlororaphis & IAM $12354^{\mathrm{T}}$ & 41 & 37 \\
\hline Pseudomonas flavescens & ATCC $51555^{\mathrm{T}}$ & 22 & 21 \\
\hline Pseudomonas fluorescens & IAM $12022^{\mathrm{T}}$ & 37 & 39 \\
\hline Pseudomonas mendocina & $\mathrm{JCM} 5966^{\mathrm{T}}$ & 23 & 23 \\
\hline Pseudomonas stutzeri & IAM $12668^{\mathrm{T}}$ & 21 & 19 \\
\hline
\end{tabular}

* FPC, Fish Pathogen Collection, University of Tokyo, Tokyo, Japan; ATCC, American Type Culture Collection, Manassas, VA, USA; IAM, Institute of Applied Microbiology, University of Tokyo, Tokyo, Japan; JCM, Japan Collection of Microorganisms, The Institute for Physical and Chemical Research (RIKEN), Saitama, Japan.

98.9\%; Pseudomonas putida biovar B MnB1, 99.6\%; Pseudomonas stutzeri ATCC 17591, 97.8\%.

\section{DNA-DNA hybridization}

DNA-DNA hybridization experiments were performed with other Pseudomonas species selected by consideration of phenotypic characteristics and 16S rRNA gene sequence analysis. The reference Pseudomonas species and the results in this experiment are given in Table 2. Levels of DNA similarity between the two isolated strains and the reference Pseudomonas species were all less than $50 \%$, and ranged from 19 to $47 \%$ (Table 2). Four isolates obtained from different places showed more than $90 \%$ DNA homology.

\section{DNA base composition}

The $\mathrm{G}+\mathrm{C}$ content of Pseudomonas plecoglossicida FPC $951^{\mathrm{T}}$ was $62.8 \mathrm{~mol} \%$ as determined by the thermal denaturation procedure.

\section{DISCUSSION}

The six isolates examined in this study were found to represent one homogeneous group of bacteria and are thought to belong to a single species. They were placed in the genus Pseudomonas (Palleroni, 1984) on the basis of their phenotypic characteristics.

According to Bergey's Manual of Systematic Bacteriology (Palleroni, 1984), the new species is classified 
phenotypically by the following key characteristics: poly- $\beta$-hydroxybutyrate is not accumulated as a carbon reserve material, fluorescent pigment is produced, and arginine dihydrolase is present. Although the bacterium is phenotypically similar to Pseudomonas aeruginosa, Pseudomonas fluorescens, Pseudomonas chlororaphis, Pseudomonas aureofaciens and Pseudomonas putida, it can be clearly distinguished from them all, except Pseudomonas putida, by gelatin liquefaction (Table 1).

The results of comparative analysis of the 16S rRNA gene sequence showed that Pseudomonas plecoglossicida FPC $951^{\mathrm{T}}$ belonged to rRNA group I, which is the genus Pseudomonas sensu stricto (Fig. 2) (Kersters et al., 1996). Furthermore, the species which had the highest similarity with Pseudomonas plecoglossicida $\mathrm{FPC} 951^{\mathrm{T}}$ was Pseudomonas putida biovar B, strain MnB1 (= ATCC 23483) (99.6\%), and the next was Pseudomonas putida biovar A, strain IAM $1236^{\mathrm{T}}$ $\left(=\right.$ ATCC $\left.12633^{\mathrm{T}}\right)(98 \cdot 6 \%)$. From the phylogenetic tree (Fig. 2) and the levels of 16S rDNA similarity, there is no doubt that Pseudomonas plecoglossicida FPC $951^{\mathrm{T}}$ is assigned to rRNA group I and is most closely related to Pseudomonas putida.

Concerning the 16S rRNA gene sequence, around 20 different Pseudomonas putida sequences have been registered in the DDBJ database. Most of them are rather short, with lengths about $1330 \mathrm{bp}$. Moore et al. (1996) reported that 1344 nucleotide positions were conserved in all Pseudomonas species, so we selected $\sim 1450 \mathrm{bp}$ sequences, not those shorter ones, for $16 \mathrm{~S}$ rDNA sequence analysis in this study. The level of $16 \mathrm{~S}$ rDNA similarity between Pseudomonas plecoglossicida FPC $951^{\mathrm{T}}$ and Pseudomonas putida biovar B MnB1 was more than $99 \%$, but they were clearly different in phenotypic characteristics (Table 1) and DNA-DNA homology (Table 2). Some papers report that $16 \mathrm{~S}$ rDNA sequences are so conservative that they are appropriate for determining inter- and intrageneric relationships but not useful in defining species (Fox et al., 1992; Stackebrandt \& Goebel, 1992).

DNA-DNA hybridization was performed with Pseudomonas plecoglossicida FPC $951^{\mathrm{T}}$ and FPC 941 and reference strains selected on the basis of phenotypic characterization and $16 \mathrm{~S}$ rDNA similarity. To investigate highly related organisms at the species level, DNA-DNA hybridization experiments are indispensable. At present, the phylogenetic definition of a species generally includes strains with approximately $70 \%$ or greater DNA-DNA relatedness (Wayne et al., 1987). DNA-DNA hybridization revealed that Pseudomonas putida biovar A ATCC $12633^{\mathrm{T}}$ had the highest homology with Pseudomonas plecoglossicida FPC $951^{\mathrm{T}}$ and FPC 941, but its value was $47 \%$ (Table 2). From this result, we conclude that Pseudomonas plecoglossicida FPC $951^{\mathrm{T}}$ and FPC 941 belong to a new Pseudomonas species.

The species Pseudomonas putida shows wide diversity phenotypically and genetically (Palleroni \&
Doudoroff, 1972; Elomari et al., 1994). In particular, Pseudomonas putida biovar A is fairly heterogeneous with respect to DNA homology and other genetic properties, but relatively homogeneous with respect to phenotypic properties (Palleroni \& Doudoroff, 1972). The species, for example, was classified into one or two groups by commercialized systems phenotypically (Grimont et al., 1996), while it was classified into more than four groups by ribotyping (Brosch et al., 1996), and had $3 \%$ diversity in $16 \mathrm{~S}$ rRNA gene sequence genetically (Moore et al., 1996). There has been room for argument on the grouping of Pseudomonas putida (Barrett et al., 1986) as stated above. Our new isolate is sure to be close to Pseudomonas putida, but it can be distinguished by the following characteristics: a positive nitrate reduction (Elomari et al., 1994) and no utilization of D-malate, L- $(+)$-tartrate, $m$-tartrate or nicotinate as sole carbon source divide it from Pseudomonas putida biovar A; while no growth at $4{ }^{\circ} \mathrm{C}$ and no use of L-arabinose, testosterone, L-tryptophan, L-kynurenine, anthranilate or nicotinate as sole carbon source divide it from Pseudomonas putida biovar B (Table 1).

In addition to the differences above, results from the 16S rDNA sequence analysis and DNA-DNA hybridization confirm that the organism is different from all Pseudomonas species previously published and should be recognized as a new species, for which we propose the name Pseudomonas plecoglossicida sp. nov.

\section{Description of Pseudomonas plecoglossicida sp. nov.}

Pseudomonas plecoglossicida (ple.co.glos.si.ci'da. M.L. masc. n. Plecoglossus systematic name of a fish genus; L. suffix masc. n. -cida killer; M.L. masc. n. plecoglossicida the killer of Plecoglossus, the genus to which ayu belongs).

Cells are Gram-negative rods $(0.5-1 \times 2.5-4.5 \mu \mathrm{m})$, and are motile by means of polar multitrichous flagella, and in some cases exhibit single or no flagellum. Intracellular granules of poly- $\beta$-hydroxybutyrate are not accumulated. Metabolism is oxidative. Growth occurs at temperatures between 10 and $30^{\circ} \mathrm{C}$ in the presence of $0-5 \%(\mathrm{w} / \mathrm{v}) \mathrm{NaCl}$. Catalase and cytochrome oxidase are produced. Fluorescent pigment is produced weakly on King medium B. Hydrolysis of gelatin, starch and Tween 80 is negative. Lecithinase is not produced. Arginine dihydrolase is produced. Lysine and ornithine are not decarboxylated. These organisms are not able to form levan from sucrose. They reduce nitrate to nitrite but do not denitrificate it to $\mathrm{N}_{2}$ gas. They are haemolytic on blood agar. They utilize the following substrates as sole carbon sources for growth: caprate, succinate, citrate, L-alanine, $\beta$-alanine, L-aspartate, L-glutamate, L-arginine, Ltyrosine, glucose, D-fructose, gluconate, 2-ketogluconate, D-malate, propylene glycol, ethanol, n-butanol, phenyl acetate, glycine, L-leucine, L-valine, L-lysine, L-ornithine, L-citrulline, L-histidine and 
L-phenylalanine. They do not use the following compounds as sole carbon sources: maltose, cellobiose, lactose, starch, inulin, L-threonine, mannitol, D-xylose, L-arabinose, L-rhamnose, D-mannose, D-galactose, sucrose, trehalose, adipate, D- $(-)$-tartrate, L- $(+)$-tartrate, $m$-tartrate, erythritol, sorbitol, $m$-inositol, adonitol, geraniol, phenol, testosterone, L-tryptophan, L-kynurenine, anthranilate or nicotinate. The following enzymes are produced (determined by using API $\mathrm{ZYM})$ : alkaline phosphatase, caprylate esterase $\left(\mathrm{C}_{8}\right)$, leucine arylamidase, valine arylamidase, trypsin, acid phosphatase and phosphoamidase. The following enzymes are not produced (determined by using API ZYM): butyrate esterase $\left(C_{4}\right)$, myristate lipase $\left(C_{14}\right)$, cystine arylamidase, chymotrypsin, $\alpha$-galactosidase, $\beta$ galactosidase, $\beta$-glucuronidase, $\alpha$-glucosidase, $\beta$-glucosidase, $N$-acetyl- $\beta$-glucosaminidase, $\alpha$-mannosidase or $\alpha$-fucosidase. The $\mathrm{G}+\mathrm{C}$ content of the DNA is $62.8 \mathrm{~mol} \%$. The type strain is FPC $951^{\mathrm{T}}$; it has been deposited in the American Type Culture Collection, Manassas, VA, USA, as strain ATCC $700383^{\mathrm{T}}$. This strain was isolated in 1994 from bacterial haemorrhagic ascites of ayu (Plecoglossus altivelis) in Tokushima Prefecture, Japan. One additional strain, FPC 941 (= ATCC 700384), which was isolated in 1994 from the diseased ayu in Shiga Prefecture in Japan, is a reference strain of this species.

\section{ACKNOWLEDGEMENTS}

The authors thank Professor K. Ohwada, Ocean Research Institute, University of Tokyo, for his helpful advice. We also thank Dr T. Iida, Department of Animal, Grassland and Fishery Sciences, Faculty of Agriculture, Miyazaki University, for his help with determination of $\mathrm{G}+\mathrm{C}$ contents.

\section{REFERENCES}

Barrett, E. L., Solanes, R. E., Tang, J. S. \& Palleroni, N. J. (1986). Pseudomonas fluorescens biovar $\mathrm{V}$ : its resolution into distinct component groups and the relationship of these groups to other $P$. fluorescens biovars, $P$. putida, and to psychrophilic pseudomonads associated with food spoilage. J Gen Microbiol 132, 2709-2721.

Brosch, R., Lefèvre, M., Grimont, F. \& Grimont, P. A. D. (1996). Taxonomic diversity of pseudomonads revealed by computerinterpretation of ribotyping data. Syst Appl Microbiol 19, 541-555.

Elomari, M., Izard, D., Vincent, P., Coroler, L. \& Leclerc, H. (1994). Comparison of ribotyping analysis and numerical taxonomy studies of Pseudomonas putida biovar A. Syst Appl Microbiol 17, 361-369.

Ezaki, T., Dejsirilert, S., Yamamoto, H., Takeuchi, N., Liu, S. \& Yabuuchi, E. (1988). Simple and rapid genetic identification of Legionella species with photobiotin-labeled DNA. J Gen Appl Microbiol 34, 191-199.

Fox, G. E., Wisotzkey, J. D. \& Jurtshuk, P., Jr (1992). How close is close: $16 \mathrm{~S}$ rRNA sequence identity may not be sufficient to guarantee species identity. Int J Syst Bacteriol 42, 166-170.

Grimont, P. A. D., Vancanneyt, M., Lefèvre, M., Vandemeulebroecke, K., Vauterin, L., Brosch, R., Kersters, K. \& Grimont, F. (1996). Ability of Biolog and Biotype-100 systems to reveal the taxonomic diversity of the pseudomonads. Syst Appl Microbiol 19, 510-527.

Hatai, K., Egusa, S., Nakajima, M. \& Chikahata, H. (1975). Pseudomonas chlororaphis as a fish pathogen. Bull Jpn Soc Sci Fish 41, 1203.

Hiraishi, A., Hoshino, Y. \& Satoh, T. (1991). Rhodoferax fermentans gen. nov., sp. nov., a phototrophic purple nonsulfur bacterium previously referred to as the "Rhodocyclus gelatinosus-like' group. Arch Microbiol 155, 330-336.

Ishimaru, K., Akagawa-Matsushita, M. \& Muroga, K. (1995). Vibrio penaeicida sp. nov., a pathogen of kuruma prawns (Penaeus japonicus). Int J Syst Bacteriol 45, 134-138.

Kersters, K., Ludwig, W., Vancanneyt, M., Vos, P. D., Gillis, M. \& Schleifer, K. (1996). Recent changes in the classification of the pseudomonads: an overview. Syst Appl Microbiol 19, 465-477.

Kimura, M. (1980). A simple method for estimating evolutionary rates of base substitutions through comparative studies of nucleotide sequences. J Mol Evol 16, 111-120.

King, E. O., Ward, M. K. \& Raney, D. E. (1954). Two simple media for the demonstration of pyocyanin and fluorescin. $J$ Lab Clin Med 44, 474-477.

Kusuda, R. \& Toyoshima, T. (1976). Characteristics of a pathogenic Pseudomonas isolated from cultured yellowtail. Fish Pathol 11, 133-139.

Kusuda, R., Toyoshima, T. \& Nishioka, J. (1974). Characteristics of a pathogenic Pseudomonas isolated from cultured crimson sea breams. Fish Pathol 9, 71-78.

MacFaddin, J. F. (1980). Biochemical Tests for Identification of Medical Bacteria, 2nd edn. Baltimore: Williams \& Wilkins.

Marmur, J. \& Doty, P. (1962). Determination of the base composition of deoxyribonucleic acid from its thermal denaturation temperature. J Mol Biol 5, 109-118.

Miyashita, T. (1984). Pseudomonas fluorescens and Edwardsiella tarda isolated from diseased tilapia. Fish Pathol 19, 45-50.

Moore, E. R. B., Mau, M., Arnscheidt, A., Böttger, E. C., Hutson, R. A., Collins, M. D., Peer, Y. V. D., Wachter, R. D. \& Timmis, K. N. (1996). The determination and comparison of the 16S rRNA gene sequences of species of the genus Pseudomonas (sensu stricto) and estimation of the natural intrageneric relationships. Syst Appl Microbiol 19, 478-492.

Nakai, T., Hanada, H. \& Muroga, K. (1985). First records of Pseudomonas anguilliseptica infection in cultured ayu, Plecoglossus altivelis. Fish Pathol 20, 481-484.

Palleroni, N. J. (1984). Genus I. Pseudomonas Migula 1894, $237^{\mathrm{AL}}$ (nom. cons. opin. 5, jud. comm. 1952, 237). In Bergey's Manual of Systematic Bacteriology, vol. 1, pp. 141-199. Edited by N. R. Krieg \& J. G. Holt. Baltimore: Williams \& Wilkins.

Palleroni, N. J. \& Doudoroff, M. (1972). Some properties and taxonomic subdivisions of the genus Pseudomonas. Annu Rev Phytopathol 10, 73-100.

Palleroni, N. J., Kunisawa, R., Contopoulou, R. \& Doudoroff, M. (1973). Nucleic acid homologies in the genus Pseudomonas. Int J Syst Bacteriol 23, 333-339.

Saiki, R. K., Gelfand, D. H., Stoffel, S., Scharf, S. J., Higuchi, R., Horn, G. T., Mullis, K. B. \& Erlich, H. A. (1988). Primer-directed enzymatic amplification of DNA with a thermostable DNA polymerase. Science 239, 487-491.

Saitou, N. \& Nei, M. (1987). The neighbor-joining method: a new method for reconstructing phylogenetic trees. Mol Biol Evol 4, 406-425.

Segers, P., Vancanneyt, M., Pot, B., Torck, U., Hoste, B., 
Dewettinck, D., Falsen, E., Kersters, K. \& Vos, P. D. (1994). Classification of Pseudomonas diminuta Leifson and Hugh 1954 and Pseudomonas vesicularis Büsing, Döll, and Freytag 1953 in Brevundimonas gen. nov. as Brevundimonas diminuta comb. nov. and Brevundimonas vesicularis comb. nov., respectively. Int $J$ Syst Bacteriol 44, 499-510.

Shiose, J., Wakabayashi, H., Tominaga, M. \& Egusa, S. (1974). A report on a disease of cultured carp due to a capsulated Pseudomonas. Fish Pathol 9, 79-83.

Stackebrandt, E. \& Goebel, B. M. (1992). Taxonomic note: a place for DNA-DNA reassociation and 16S rRNA sequence analysis in the present species definition in bacteriology. Int $J$ Syst Bacteriol 44, 846-849.

Stanier, R. Y., Palleroni, N. J. \& Doudoroff, M. (1966). The aerobic pseudomonads: a taxonomic study. J Gen Microbiol 43, 159-271.

Tamaoka, J., Ha, D. M. \& Komagata, K. (1987). Reclassification of Pseudomonas acidovorans den Dooren de Jong 1926 and Pseudomonas testosteroni Marcus and Talalay 1956 as Comamonas acidovorans comb. nov. and Comamonas testosteroni comb. nov., with an emended description of the genus Comamonas. Int J Syst Bacteriol 37, 52-59.

Thompson, J. D., Higgins, D. G. \& Gibson, T. J. (1994). CLUSTAL $\mathrm{W}$ : improving the sensitivity of progressive multiple sequence alignment through sequence weighting, position-specific gap penalties and weight matrix choice. Nucleic Acids Res 22, 4673-4680.

Véron, M. (1975). Nutrition et taxonomie des Enterobacteriaceae et bacteries voisines. I. Methods d'étude des auxanogrammes. Ann Microbiol Inst Pasteur 126A, 267-274.

Wakabayashi, H. \& Egusa, S. (1972). Characteristics of a Pseudomonas sp. from an epizootic of pond-cultured eels (Anguilla japonica). Bull Jpn Soc Sci Fish 38, 577-587.

Wakabayashi, H., Sawada, K., Ninomiya, K. \& Nishimori, E. (1996). Bacterial hemorrhagic ascites of ayu caused by Pseudomonas sp. Fish Pathol 31, 239-240.

Wayne, L. G., Brenner, D. J., Colwell, R. R. \& 9 other authors (1987). International Committee on Systematic Bacteriology. Report of the ad hoc committee on reconciliation of approaches to bacterial systematics. Int J Syst Bacteriol 37, 463-464.

Weisburg, W. G., Barns, M. S., Pelletier, A. D. \& Lane, J. D. (1991).
16S ribosomal DNA amplification for phylogenetic study. $J$ Bacteriol 173, 697-703.

Willems, A., Busse, J., Goor, M. \& 8 other authors (1989). Hydrogenophaga, a new genus of hydrogen-oxidizing bacteria that includes Hydrogenophaga flava comb. nov. (formerly Pseudomonas flava), Hydrogenophaga palleronii (formerly Pseudomonas palleronii), Hydrogenophaga pseudoflava (formerly Pseudomonas pseudoflava and 'Pseudomonas carboxyflava'), and Hydrogenophaga taeniospiralis (formerly Pseudomonas taeniospiralis). Int J Syst Bacteriol 39, 319-333.

Willems, A., Falsen, E., Pot, B., Jantzen, E., Hoste, B., Vandamme, P., Gillis, M., Kersters, K. \& Ley, J. D. (1990). Acidovorax, a new genus for Pseudomonas facilis, Pseudomonas delafieldii, E. Falsen (EF) group 13, EF group 16, and several clinical isolates, with the species Acidovorax facilis comb. nov., Acidovorax delafieldii comb. nov., and Acidovorax temperans sp. nov. Int $J$ Syst Bacteriol 40, 384-398.

Wilson, K. (1987). Preparation of genomic DNA from bacteria. In Current Protocols in Molecular Biology, pp. 2.4.1.-2.4.2. Edited by F. M. Ausubel, R. Brent, R. E. Kingston, D. D. Moore, J. G. Seidman, J. A. Smith \& K. Struhl. New York: Wiley.

Yabuuchi, E., Yano, I., Oyaizu, H., Hashimoto, Y., Ezaki, T. \& Yamamoto, H. (1990). Proposals of Sphingomonas paucimobilis gen. nov. and comb. nov., Sphingomonas parapaucimobilis sp. nov., Sphingomonas yanoikuyae sp. nov., Sphingomonas adhaesiva sp. nov., Sphingomonas capsulata comb. nov., and two genospecies of the genus Sphingomonas. Microbiol Immunol 34, 99-119.

Yabuuchi, E., Kosako, Y., Oyaizu, H., Yano, I., Hotta, H., Hashimoto, Y., Ezaki, T. \& Arakawa, M. (1992). Proposal of Burkholderia gen. nov. and transfer of seven species of the genus Pseudomonas homology group II to the new genus, with the type species Burkholderia cepacia (Palleroni and Holmes 1981) comb. nov. Microbiol Immunol 36, 1251-1275.

Yabuuchi, E., Kosako, Y., Oyaizu, H., Yano, I., Hotta, H. \& Nishiuchi, Y. (1995). Transfer of two Burkholderia and an Alcaligenes species to Ralstonia gen. nov. : proposal of Ralstonia pickettii (Ralston, Palleroni and Doudoroff 1973) comb. nov., Ralstonia solanacearum (Smith 1896) comb. nov. and Ralstonia eutropha (Davis 1969) comb. nov. Microbiol Immunol 39, 897-904. 